\title{
NAHIYES OF THE SANJAK OF PAKRAC: THE UNKNOWN NAHIYE OF KONTOVAC
}

\section{Fazileta Hafizović}

Oriental Institute, Sarajevo

\section{ABSTRACT}

This paper is based on data from Ottoman cadastral surveys for the sanjak of Pakrac. Not much work has been done about this sanjak based on Ottoman sources, and there are cases where the surveys are only partially correct or entirely incorrect. Even the names of some nahiyes were not read correctly, which is due to the fact that the scripture in the two records used here is extremely incomprehensible. Also, many of the settlements cannot be pinpointed today using their names from that time, which complicates the identification of these administrative units. However, data from these surveys was helpful in identifying previously unknown nahiye of Kontovac.

Ottoman sources for the sanjak of Pakrac ${ }^{1}$ are the least investigated archival documents among all others regarding its former territory. The very position and status of this sanjak among other sanjaks in this area made it, in our opinion, to be paid less attention by the Ottoman administration in comparison with other neighbouring territorial units. ${ }^{2}$ In addition, constant fights between the Ottomans and their enemies caused destruction of a large part of Ottoman administration's documentation. After the Ottomans left, the documentation was obviously completely destroyed, and if anything had remained, it was saved by the Ottoman enemies and carried to their archives. ${ }^{3}$

However, the Ottoman cadastral surveys, Tapu tahrir defterleri, were always written in two copies, one of which remained in the provincial, while the other was send to the central administration. Thus, these sources are most often preserved in the archives of the central administration.

1 Common assumption is that the sanjak of Pakrac changed its name depending on the location of the seat of sanjakbey: Čazma/Začasna, Pakrac, Cernik. However, according to the documents processed here, the following can be said: in cadastral surveyss, from the 16th century at least, the sanjak was named after Pakrac, while in the same period in documents from Muhimme defters it was repeatedly called the sanjak of Začasna, even though sanjakbey could not have resided there as the fort was already destroyed. According to H. Šabanović, that had happened in 1559 . Hazim Šabanović, Bosanski pašaluk (Sarajevo, 1982), 67.

2 Nenad Moačanin talks about it in his book Slavonija i Srijem u razdoblju osmanske vladavine (Slavonski Brod: Hrvatski institut za povijest, Podružnica za povijest Slavonije, Srijema i Baranje, 2001), 112.

3 The most famous is the case of the capture of the entire archive of Osman Pasha Kazanac by the Habsburgs in the battlefield after the defeat at Vienna in 1683. The archive ended up in Karlsruhe: Franz Babinger, Das Archiv des Bosniaken Osman Pascha (Berlin, 1931). In addition, State Archive in Vienna holds some of cadastral survey records of the sanjak of Požega, which have been extensively used, especially by Nenad Moačanin. 
Other documents, such as sijils, protocols from judges of certain judicial units, which were named after the seat of the judge/kadi, were not treated the same. They were written as a single copy, and contained very important material, from local cases to correspondence with the capital, all of which was neatly registered.

As far as the cadastral surveys for the sanjak of Pakrac are concerned, two extensive defters from the $16^{\text {th }}$ century are saved, to our knowledge. These surveys are kept in the Ottoman archive of the Archive of the Prime Ministry in Istanbul (İstanbul Başbakanlık Osmanlı Arşivi, henceforth BOA), where all similar surveys for all parts of the former Ottoman Empire are being kept. The first defter is labelled as BOA TTD no. 355, finished in $1565 .{ }^{4}$ It has only 112 pages. The second defter is labelled as BOA TTD no. 612 from $1584 .^{5}$ It has in total 115 pages, as the last page is blank. ${ }^{6}$

Defters mentioned above are not complete censuses of this sanjak, but surveys of parts of population, partially agrarian, but mostly of Vlach status and descent. Such way of surveying is characteristic of the $16^{\text {th }}$ century, as can be seen in other sanjaks in the area. Namely, certain categories of population were surveyed separately, in accordance with their status. This is especially visible in the case of Vlach population, fort crews, and the like.?

On the basis of the content of these surveys we can say that they did not include urban and military centres of the sanjak of Pakrac, fortified towns with kasaba status, where actually the most of population lived, both civilians and military. Population with Vlach status was not present in the kasabas, which is why these surveys show only a partial number of houses in the sanjak. ${ }^{8}$

4 Defter was dated to third decade of the month of Jumada al-Ula, $973 \mathrm{AH}$, which corresponds to a period between December 14 and 24, 1565.

5 At the beginning of the survey it was noted that it had been done in $992 \mathrm{AH}$, without a closer date. 992 AH lasted from January 14, 1584 to January 2, 1585 AD.

6 Copies of these two surveys existed in the Oriental Institute in Sarajevo for several decades. However, since the handwriting in both cases, especially in the 1584 survey, is very bad and difficult to read, it was very hard to work with those copies. Luckily, the Ottoman Archive in Istanbul (BOA) performs digitalization of documents in order to preserve the better, so we had access to digitalized form of these censuses, which made the work easier. I am very thankful to Ayten Ardel, archivist in the mentioned archive for providing me these digitalized forms.

7 One example is with the survey of the sanjak of Klis from 1550, where firstly an extensive population census was made, who were listed in timars, zeamets or has. See Fehim Spaho, Opsirni popis Kliškog sandžaka iz 1550. godine, (Sarajevo: Orijentalni institut, 2007). After that a list of timars of fort crew in the sanjak was made, complimentary to the firstly mentioned census: Fazileta Hafizović, Opsirni popis timara mustahfiza turdava Kliškog sandžaka (Sarajevo: Institut "Ibn Sina," 2014). Each of these had its summary variant, icmal defteri, where alongside the names of estate owners complete population was not written, rather only source of incomes (village, forest, mill, etc)

8 It would be necessary to find other surveys of this sanjak, it is known there are at least some in Basbakanlik Osmanlı Arsivi in Istanbul. They might not have been catalogized when the Oriental Institute got the first two (which was half a century ago), but in recent times, many of the documents in this archives were revised and processed. We can only mention one census from 1604 in the Oriental Institute, named Icmal (summary) defter of zeamets and timars of Bosna, 
In addition, there were cases that some villages were not registered in the cadastral surveys at all. This usually happened with villages mainly populated by the Vlachs, especially in mountainous and inaccessible areas, when a surveyor would not tour the land, and local knezes and premikürs, who were obliged to bring the population and provide the necessary data, would simply not show up. This was happening in the sanjak of Začasna/Pakrac, too. ${ }^{9}$ The knezes played a significant role and were important associates of the Ottoman government; Knez Vukmir, who was described as advocating for royal revenues quite diligently, had a timar of 3.000 akce. $^{10}$

The first survey of the sanjak of Pakrac from 1565 is the result of a survey conducted in the sanjaks of Rumeli the same year (including censuses from the sanjaks of Požega, Bosna, etc.). It is possible that it was also a part of the first survey of this sanjak ever, as the sanjak itself had been established only a decade earlier. ${ }^{11}$ The significant thing is that in the detailed survey of the sanjak of Bosna from 1540, a large part of territory that would later become the sanjak of Pakrac was recorded. ${ }^{12}$ The nahiye of Cernik was listed alongside its villages, as well as some villages that belonged to Bijela Stijena and Gradiška. This would mean that the nahiye of Cernik was not mentioned for the first time in 1550 , but ten years earlier. ${ }^{13}$ This defter is referred to by the formulation at the beginning of the 1565 survey: "Further on, this is the new extensive survey of the liva of Pakrac,", as well as in a short legal directive about taxation, also listed at the beginning of the survey: "Hungarians and other infidels, found in the nahiyes of Drenovci and Cernik, in the mentioned liva, under

Klis, Pakrac and Herzegovina which had not been processed yet. Istanbul BOA TTD No. 728. The defter is from a fund that Academy of Sciences of Bosnia and Herzegovina has placed to the Institute's disposal, where it is filed under number 230.

9 In the Muhhime defter from 1565 there was a document which analyzed the situation in the sanjaks of Bosna, Klis, Začasna, Požega and Srijem, where the intendant of mukaatas mentioned: in the above mentioned sanjaks there is a lot of hidden possessions, lost property belonging to the Beytul-mal, and many villages, mezraas, mills, farms, smiths not included in the defter. Muhimme defter from the 16th century, signatures in the Oriental Institute OIS ANUBIH 139, translated by Abdulah Polimac, in scripture, p. 91-96.

10 The amount of income from timars points that this knez had to have an important role in communication between the government and his subordinates, as the amount is double of the usual income for timar of fort crew. Although the text has a note "He converted to Islam and was given a name Sefer", it is important that he had the privilege of that timar twice already as a nonMuslim. Muhimme defter from $16^{\text {th }}$ century, signatures in Oriental Institute OIS ANUBIH 139, translation by Abdulah Polimac, in scripture p. 22.

11 H. Šabanović states that Začasna sanjak, or Pakrac, was established in 1557 (HŠabanović, Bosanski pašaluk, 223), while N. Moačanin states the year 1552 as the year of its establishment (Moačanin, Slavonija i Srijem u razdoblju osmanske vladavine, 8).

12 Opširni popis sandžaka Bosna iz 1540. godine, BOA TTD 432. The census is not processed, and it consists of two parts (BOA TTD No. 211 and BOA TTD No. 432) and has almost 900 copies, twice the number of defter pages.

13 Šabanović, Bosanski pašaluk, 224. 
the provisions of the old survey were written as such..." ${ }^{14}$. Also noticeable is the fact that in the same year of 1540 the sanjak of Požega was surveyed, but the nahiye of Cernik was not listed as a part of it, but rather as a part of the sanjak of Bosna. This could be due to the fact that the sanjak of Požega itself was a newly established unit, but also because, as N. Moačanin said, "western Slavonia was administratively and politically more connected to Bosnia than it was to the lowlands in the east". ${ }^{15}$

This survey had the following nahiye listed: Cernik, Drenovci, Pakrac, Bijela Stijena, Kutinovci, Šagovina, Podbučje, Sirač, Dobra Kuća, Čaklovci, Stupčanica, Pakarska Sredel, Kontovac i Podvrški. The nahiye of Podborje, mentioned by $\mathrm{H}$. Šabanović, ${ }^{16}$ was not found in either of the two surveys, while, on the contrary, he does not mention the nahiye of Podbučje at all. ${ }^{17}$ In comparison to the villages that can be pinpointed, the nahiye of Podbučje was located west of Požega, most likely neighbouring Orljava nahiye. However, the village of Bučje, which could be connected to the nahiye's name, was addressed in the nahiye of Drenovac, without a mention of a fort or a suburb. ${ }^{18}$ As for the nahiye of Podvrški, it was listed at the end of both surveys, which could point to it being near the border. But, judging by the only recorded village, Hrgodol, it can be located as an estate and a fort of the same name, north of Cernik. As the estates of Sv. Stjepan, Laholc, Deževci, Kovačica and Hrgodol ${ }^{19}$ all belonged to the capitol of Podvrško, it is certain that this is the precise area. However, it is noted that this nahiye was formed in the area with multiple nahiyes including Cernik, Drenovci, Šagovina, Bijela Stijena and Podbučje. It had to have villages with agrarian population, as it would not make sense to establish a nahiye for a single village.

The largest nahiye was certainly Cernik, ${ }^{20}$ followed by Drenovci and Pakrac as nahiyes having slightly less villages than Cernik, while the remaining nahiyes were fairly small, with border nahiyes even being without population, with deserted villages- Stupčanica had one populated village and fourteen deserted villages, Pakarska Sredel had three populated villages and the nahiye of Kontovac had five unpopulated villages. On the initial glance, territory of this sanjak appeared quite

14 New extensive census of Pakrac liva is this one from 1565, whilst the "directive of the old census" refers to the directives of the census of Bosna sanjak from 1540.

15 Moačanin, Slavonija i Srijem u razdoblju osmanske vladavime, 1.

16 Village of Podborje, 2 houses, in the nahiye of Dobra Kuća, BOA TTD No. 355/53.

17 BOA TTD No. 355/50-51.

18 Ibid, f. 26. Along with its three neighborhood, the village had 30 houses.

19 Službene stranice općine Cernik, "Podvrško," https://www.cernik.hr/podvrsko.html (accessed 10 November 2019).

20 S. Ural considers Bijela Stijena as the largest nahiye. Bijela Stijena has more villages and mezreas (Selcuk Ural, "Pakrački sandžak u drugoj polovici XVI stoljeća," Scrinia Slavonica 11, no. 1 (2011): 74.), but those are villages with a small numbers of residents. Same author in the table 2 of the same work lists Cernik and Drenovci as having most houses. 
unusual; however, knowing this territory was inhabited by Vlach population makes it clearer why these nahiyes were so unevenly arranged. It is known the Ottomans had the habit of settling Vlach population in the borderlands, in the estates left by the local population after the arrival of the Ottomans, giving them certain benefits for the migration. They were the belt between the Ottomans and their enemies, although this Vlach barrier was not reliable or secure at all. As nomads who were used to travelling across this region for centuries before the Ottoman arrival, they found it hard to adapt to sedentary way of life, especially in these areas of constant quarrel, despite the proclaimed peace.

In the survey of 1584 , which was created during surveying sanjaks in the wider area, same nahiyes were listed as earlier- Cernik, Drenovci, Pakrac, Bijela Stijena, Kutinovci, Šagovina, Podbučje, Sirač, Dobrokućani, Čaklovci, Stupčanica, Pakarska Sredel, Kontovac i Podvrški. Based on the listed number of Vlach houses paying the filuri tax, which was 407 as opposed to 386 listed in the earlier survey, it is visible that there was a small population increase. The villages of the nahiye of Stupčanica were not deserted anymore, while the nahiye of Kontovac remained deserted, with the only Vlach village in the nahiye of Podvrški was now likewise deserted.

The number of houses is not in proportion with the data from H. Petrić, who studied the topic of Vlach emigration from the area covered by the sanjak of Pakrac. His data speaks of thousands of emigrated Vlach families, meaning a lot more individuals. ${ }^{21}$ It is hard to say how that happened - Ottoman censuses records were from that period, but did not show remotely the same number of families. It is also not plausible that they were settlers of villages that escaped surveyors, as it could not have been such a large number of villages. These were probably Vlach nomads, who passed the area, never lingering long enough to be registered, and arriving from area wider than the area of this sanjak.

Interpretation of the text presents a large obstacle, along with the discovery of the locations listed in the survey. Many of them are hard to find today, partly due to name changes and partly because they are gone. It is possible that remnants of some names can be found in nearby areas (plains, hills, etc.), but their discovery would have to be a result of extensive field research. This issue is spoken about by S. Andrić: "Locations of some of these settlements are difficult to pinpoint as they have disappeared completely in early modern toponymy or have survived into the early modern period, but under different names“. ${ }^{22}$

21 Hrvoje Petrić, “O iseljavanju vlaškog stanovništva iz zapadnog Papuka, Ravne gore i Psunja te susjednih područja krajem 16. i početkom 17. stoljeća”, Zbornik Janković 1, no. 1 (2015): 50.

22 Stanko Andrić, "Šuma Garavica i 'ničija zemlja' na slavonsko-turskom pograničju u 16. i 17. stoljeću," in Slavonske sume kroz povijest. Zbornik radova znanstvenog skupa s medunarodnim sudjelovanjem održanog u Slavonskom Brodu 1.-2. listopada 2015., ed. Dinko Župan and Robert Skenderović, (Slavonski Brod: Hrvatski institut za povijest - Podružnica za povijest Slavonije, Srijema i Baranje, 2018), 65. 
One of the nahiyes whose identification was problematic is the nahiye of Kontovac. It is already noted that the writing of the defter is extremely complicated to read, so some ligatures could give a different variant of the name. However, comparing several versions of the same name reveals the correct variant. It was precisely this method, through which the ligature was solved in the case of names in this nahiye.

The nahiye of Kontovac was formed around the fort of the same name that belonged to the palatine Nikola Kont ${ }^{23}$, a high officer in the Hungarian court, founder of the later famed noble house from Slavonia, the Iločki, and great-grandfather of Nikola V Iločki who, amongst other titles, had been named the king of Bosnia. ${ }^{24}$ The fortress was built as a residence for the landlord and his family, and also for protection during wartime, or as S. Andrić said: "Just like towns and trade centers, fortresses and castles were also geographically uniformly distributed near the end of the Middle Ages, as a reflection of the attempts of many noblemen to secure themselves such residences and warehouses for goods, especially during wartime".25 Additionally, as almost every fortress had a suburb, it was, as a trade center, source of income for nobles, and also for Ottoman government later on.

During the Middle Ages, the fortress of Kontovac was located in the county of Križevac, which was one of the most densely populated areas of the HungarianCroatian kingdom. ${ }^{26}$ Given that the fortress was completely abandoned after the arrival of the Ottomans, almost all the remnants have disappeared to this day. Croatian historians have managed to discover its location thanks to non-Ottoman sources. Ranko Pavleš had cited the following: "Kontovec, the second estate in question covered the area of the present-day settlements Grubišno Polje, Poljani, Gornja Rašenica, Donja Rašenica, Ivanovo Selo, Treglava, and likely Dapčevački Brđani, Velika Dapčevica, Mala Dapčevica and Turčević polje. Written history of the area of both seigniories starts in the second part of $13^{\text {th }}$ century when Gordova was noted as the name of the administrative unit of the county, and in the place of the later estate of Kontovac, the estates of Zdenci and Gornji Zdenci were listed. ${ }^{27}$

This populated area was deserted due to Ottoman conquests. Despite having all the necessary living conditions (land, forests, water), war activities, which were a constant with only the intensity changing, contributed to the abandonment of the

23 Nikola Kont died in 1367, and it is considered that he was born at the beginning of the century.

Title of the king of Bosnia was given to Nikola V Iločki by Matijaš Korvin in 1471, in his attempt to force out the Ottomans, who had already conquered the Bosnian kingdom. However, his plans failed and Nikola Iločki died in Croatia in 1477 as the "exiled Bosnian king."

25 Andrić, "Šuma Garavica," 65-66.

26 Andrić, "Šuma Garavica," 66.

27 Ranko Pavleš, "Gordova i Kontovec - dva srednjovjekovna vlastelinstva na području Grubišnog Polja”, Zbornik Janković 3, no. 3 (2018): 9. 
area. According to an Ottoman census from 1565, four deserted villages were listed in the nahiye, as well as the settlement of Kontovac, also deserted. The villages were Gornje Polje, Donje Polje, Sejano Hrastje and Lipa. The villages of Gornje Polje and Donje Polje cannot be found today under those names. The village of Sejano Hrastje is mentioned in the literature as an independent estate of nobility, ${ }^{28}$ with its location provided: "In the area of future generalate, the toponym Sinarast was listed between Đurđevac and Zdenaci, and it marks the estate of Sejano Hrastje found near the Pauline monastery of Saint Anne in the seigniory of Dobra Kuća. ${ }^{29}$ Concerning the village of Lipa, the scribe did not explicitly state it was deserted, but given that it was recorded without inscribed population and listed with other abandoned villages, it must have been deserted too. Nowadays, the village of Šuplja Lipa exists, ${ }^{30}$ and since it is located on the territory of the former estate of Kontovac, it is believed that this is the village in question.

The village-market town ${ }^{31}$ of Kontovec, although deserted itself, carries in its name remnants of its status as a suburb of a fort (varos). The survey contains a list of other settlements of the same status, some populated and others deserted: the village-market town Dvorište in the nahiye of Bijela Stijena, the village-market town of Velika Islobočina in the same nahiye, the village-market town of Sveti Vladislav in the same nahiye, the village-market town of Sveta Katarina, the same nahiye, the village-market town of Bila/Bijela in the nahiye of Bijela Kuća, the village-market town of Pakarska in the nahiye of Pakarska Sredel, the village-market town of Kontovac in the nahiye of Kontovac.

In 1565, the nahiye of Kontovac was listed in the congregation (cema'at) of Knez Radoja, son of Radiša, where also the deserted village of Vinovci was recorded, in the nahiye of Sirač, as well as 20 populated and 18 deserted villages in the nahiye of Dobra Kuća.

In 1584, the nahiye of Kontovac was listed in the congregation of Novak, son of Selak, although the former Knez Radoja, son of Radiša, was still active, even

\footnotetext{
28 "As can be deduced from scarce data available, it seems that the territory of the estate was not compact. An example would be the estate of Sejana Hrastja located near the creek Mala "Soplonca," i.e., today's Peratovici creek, which was an independent estate, possibly surrounded by lands of nobility." Pavleš, "Gordova i Kontovec," 29.

29 Mirela Slukan-Altić, "Podravsko srednjovjekovlje u zrcalu kartografskih izvora," Podravina 2 no. 4 (2003): 125.

30 The village of Šuplja Lipa is located north of Daruvar and southeast of Grubišno Polje.

31 This was the usual administrative marking of a settlement that had lost the features of a market town, but was still inhabited. It primarily means that trade was no longer practiced in the scale that would have to be taxed, which we can see in the absence of the mark that states what kind of trade was available- market tax, inspection of the market, etc. For a while, the administration would cite both characteristics, and if the former settlement would have the features of a village for a longer period, it would start to be marked as a village.
} 
listed as a resident of one of the villages in the nahiye of Dobra Kuća. ${ }^{32}$ The settlement and other villages remained deserted, and there are no new data regarding the nahiye or the villages.

\section{CONCLUSION}

Based on the data from two surveys of the sanjak of Pakrac from the $16^{\text {th }}$ century, the only ones at disposal, it was possible to clear some confusion around the names and layout of the nahiye in this sanjak. This helped in identifying the nahiye of Kontovac, unmentioned in previous works or mentioned under incorrect name.

The defters recorded mostly Vlach population, that is, the villages with mixed population, Vlach and agrarian, and villages with exclusively Vlach residents. Although the surveys usually listed only the population that was obligated to pay taxes, here only a part of that population was listed. There is no data on the population of towns, fortifications, and the like. Such data can be found in detailed surveys of sanjak population, which were divided to timars and zeamets. ${ }^{33}$ The proof that the sanjak Pakrac was administrated like that is at the end of the both defters, where the total income mentions half of the baduhava tax from sipabi timars of the mentioned liva. ${ }^{34}$

It is clear that a more detailed search for Ottoman sources regarding this sanjak, which surely exist, needs to be performed. It is a long-term project, but this would greatly contribute to create a clearer image of this area.

\section{BIBLIOGRAPHY}

\section{UNPUBLISHED SOURCES}

Başbakanlık Osmanlı Arşivi (BOA), Istanbul.

Detailed survey of the sanjak of Bosnia of 1540 - TTD No. 211 and TTD No. 432

\footnotetext{
32 Changing a knez of a nahiye would probably mean that the administration has perceived that a certain knez would be more useful in that area, and could better control the congregation. As seen from the survey of this sanjak, Vlach population was divided in several congregations, all subordinated to the knez. A congregation of one knez would extend beyond the border of the nahiye, for example, the Knez Tomul's congregation was spread over six nahiye. Besides, one nahiye could be divided over multiple congregations, such as the nahiye of Bijela Stijena, where villages were divided between congregations of three different knezes.

33 Income from Vlach population belonged to the Sultan's hass, which is why they were recorded separately.

34 BOA TTD No. 355/56.
} 
Detailed survey of the sanjak of Pakrac of 1565 - TTD No. 355

Detailed survey of the sanjak of Pakrac of 1584 - TTD No. 612

\section{LITERATURE}

Andrić, Stanko. "Šuma Garavica i „ničija zemlja“ na slavonsko-turskom pograničju u 16. i 17. stoljeću,” In Slavonske šumekrozpovijest. Zbornikradova znanstvenog skupa s medunarodnim sudjelovanjem održanog u Slavonskom Brodu 1.-2. listopada 2015., edited by Dinko Župan and Robert Skenderović, 61-117. Slavonski Brod: Hrvatski institut za povijest - Podružnica za povijest Slavonije, Srijema i Baranje, 2018.

Babinger, Franz. Das Archiv des Bosniaken Osman Pascha. Berlin, 1931.

Hafizović, Fazileta. Opširni popis timara mustahfiza turdava Kliškog sandžaka. Sarajevo: Institut "Ibn Sina," 2014.

Moačanin, Nenad. Slavonija i Srijem u razdoblju osmanske vladavine. Slavonski Brod: Hrvatski institut za povijest, Podružnica za povijest Slavonije, Srijema i Baranje, 2001.

Pálffy, Géza. "Izvanredan izvor o zemljopisnim znanjima ugarsko-hrvatske političke elite 16. stoljeća. Popis ugarskih i slavonskih gradova, utvrda i kaštela, koji su između 1526. i 1556. dospjeli u turske ruke, sastavljen za staleže Njemačko-Rimskoga Carstva.” Scrinia Slavonica 14 (2014): 9-39.

Pavleš, Ranko. "Gordova i Kontovec - dva srednjovjekovna vlastelinstva na području Grubišnog Polja.” Zbornik Janković 3, no. 3 (2018): 9-30.

Petrić, Hrvoje. "O iseljavanju vlaškog stanovništva iz zapadnog Papuka, Ravne gore i Psunja te susjednih područja krajem 16. i početkom 17. stoljeća.” Zbornik Jankovic, 1, No. 1 (2015): 39-50.

Šabanović, Hazim. Bosanski pašaluk. Sarajevo, 1982.

Slukan-Altić, Mirela. "Podravsko srednjovjekovlje u zrcalu kartografskih izvora." Podravina 2, no. 4 (2003): 121-132.

Službene stranice općine Cernik. "Podvrško" https://www.cernik.hr/podvrsko. html (accessed November 11, 2019).

Spaho, Fehim. Opširni popis Kliškog sandžaka iz 1550. godine. Sarajevo: Orijentalni institut, 2007.

Ural, Selcuk. "Pakrački sandžak u drugoj polovici XVI stoljeća." Scrinia Slavonica 11 , no. 1 (2011): 61-78. 